\title{
Assessment of the Extent and Causes of Fuelwood Collection in the Surrounding Communities of Kasewe Reserved Forest, Sierra Leone
}

\author{
${ }^{*}$ KOROMA, AH; ${ }^{2}$ MANSARAY, A; ${ }^{3}$ SESAY, A \\ ${ }^{*}$ Department of Biological Sciences, Njala University, Njala Campus, Njala, Sierra Leone \\ ${ }^{2}$ Department of Fisharies and Acquaculture, Njala University, Njala Campus, Njala, Sierra Leone \\ ${ }^{3}$ Institute of Geography and Development Studies, Njala University, Njala Campus, Njala, Sierra Leone \\ *Corresponding Author Email: alusinehkoroma@gmail.com; Other Authors Email: amidu.mansaray@njala.edu.sl; \\ sesaya@njala.edu.sl
}

\begin{abstract}
Seven (7) communities living in and around the Kasewe forest reserved were sampled to assess the extent and causes of fuelwood collection from the reserved forest involving 50 individuals in stratified random technique with a view to evaluate the degree and reasons for fuelwood collection from the Kasewe reserved forest. Data obtained indicate a high frequency of fuelwood harvest in the forest throughout the year. The significant factors affecting such decisions were availability and accessibility, ensure fast cooking process, and cost-effective. In addition, fuelwood activities were intensive throughout the year but peaks late dry season. Hence $48(96 \%)$ of respondents stated forest degradation as one of the significant threats posed by fuelwood collectors to the forest. The study indicates that $100 \%$ of the collector are unemployed this was mainly the reason why residents of those communities collect fuelwood from the reserved forest. However, this study concluded that fuelwood collectors were selective over the kind of species they harvest, but the preferred species were not replanted. Fuelwood in the study area is not restricted to domestic use as it is also sold to augment local income. The sale of fuelwood is probably the biggest threat to sustainable utilization of fuelwood and the forest. Therefore, this study recommends that alternatives sources of livelihood and energy be created, among other recommendations for resident communities that will reduce the frequency of harvest from the forest.
\end{abstract}

\section{DOI: https://dx.doi.org/10.4314/jasem.v25i7.24}

Copyright: Copyright $(\mathcal{C} 2021$ Koroma et al. This is an open access article distributed under the Creative Commons Attribution License (CCL), which permits unrestricted use, distribution, and reproduction in any medium, provided the original work is properly cited.

Dates: Received: 10 May 2021; Revised: 28 June 2021; Accepted: 01 July 2021

Keywords: Assessment, Fuelwood Collection, Kasewe Forest Reserved, Sierra Leone

Fuelwood is an especially significant forest asset in the developing world and has been the focal point of many innovative work ventures since the 'energy crisis' of the 1970s (Joanne, 1996). Human utilization of natural resources is commonly distinguished as the critical connection between human conduct and derogation of the natural environment (Stern et al., 1997). Although social examination has centered on the all-out volume of human utilization, traditional social science highlights the significance of advances in the idea of utilization as a crucial change in the manner individuals' link to their environment (Foster, 1999). Be that as it may, though forest devitalization has regularly been credited to over-dependence on fuelwood, different components like nearby nearness and access, land residency, and the local management regimes decide the degrees of misuse and supportability of woodlands and forestry resources (Soussan, 1998). The utilization of fuelwood, which alludes to both kindling and charcoal, is so critical to how individuals endure that it will be hard to separate family units from its utilization, even with the arrangement of numerous elective sources of energy (Davison, 1985; Cole-cline, 1984a.). In Sierra Leone, most firewood is a by-product of the bush-fallow farming system; some charcoal is produced that way; however, some is explicitly cut to make charcoal.
Several anthropogenic activities have led to several forests being obliterated and a general decline of existing forests. Of the myriad causes of depletion of forests, increasing fuelwood usage has been identified as one of the biggest threats to forests (Agarwala, 2006). In Sierra Leone, fuelwood collection is a common practice among rural dwellers. For some households in the provinces, it presents a significant task in the provision of energy as well as income generation. However, homes that live far away from the forest, especially in cities and towns, fuelwood, and mainly charcoal, are acquired through commercial means. Some towns receive supplies from nearby villages, but cities like Freetown, Makeni, and Waterloo, are supplied by trucks. Over the years, the demand and consumption of fuelwood have increased with increase in the human population. The increasing demand has expanded the fuelwood market and increased the distance and energy expended on the harvesting and supply of fuelwood. The trade of fuelwood in Sierra Leone offers many benefits to the rural poor and has become a significant source of income for villages with good road access that can sell to towns and cities. This has enabled some families to send their children to school and improve their general welfare. For those with sufficient capital to invest in transport facilities, trading in fuelwood is believed to 
generate substantial profits. Some fuelwood merchants are owners of a vast market of firewood and charcoal. They own Lorries that go to the villages to buy firewood from villages. Fuelwood is bought at low prices from the villages and sold for two to two and a half times the purchase price. These markets provide fuelwood for towns and cities and also provide job opportunities for a range of low-income groups. Among these groups are; the fuelwood producers or collectors, the transporting agents, and the retailers. Due to the inadequate electricity supply and the high cost of electrical appliances, Sierra Leoneans are reliant on fuelwood as a significant source of energy for domestic use. Kasewe forest reserve is one of the few forest reserves owned and managed by the Government of Sierra Leone. This forest provides direct benefits to two districts; Tonkolili and Moyamba district in the North and southern provinces, respectively. The communities around the forest comprise inhabitant from the two major tribes in Sierra Leone, the Mendes, and Themnes. As the Government of Sierra Leone centralized almost all of its activities in Freetown, coupled with the high unemployment rate and failure of the GoSL to provide alternative sources of livelihood, rural people are most active in the informal economic sector and are self-employed and economically marginalized (the majority are classed as poor by every national and international standard). Therefore, people in these communities are not an exception, and most of them find it difficult to survive since most of them do not have a guaranteed income from paid employment. As a result, they depend on the forest for firewood and charcoal burning for domestic use and commercial purpose. Various organizations, including the United Nations Food and Agriculture Organization FAO (Eckholm et al., 1984) examined the 'fuelwood crisis' using vertical approaches analogous to the postwar nutrition surveys, their analyses compared estimated fuelwood consumption with the natural growth rates of vegetation and the proportion of fuelwood that was accessible to and could be derived on a sustainable basis by, local communities. The villagers depend on the woodland for forest produce, especially fuelwood and building materials. In some nations, for example, Malawi, there are unequivocal strategies even in the National Parks concerning who can assemble fuelwood and how it can be gathered. For sure, His Excellency, Dr. H. Kamuzu Banda, the previous President of Malawi, affirmed the Park only on the condition that its creation did not physically meddle with the lifestyle of the occupants of the region (Bell, 1978). Kindling assembled from the forested lodge is a significant source of domestic energy in provincial zones of numerous developing nations (Cecelski, et al., 1979; Heltberg, et al., 2000). It has been evaluated that more than 2.4 billion individuals depend legitimately on customary biomass powers for their cooking and warming, and in developing, nations biomass use speaks to over portion of residential energy utilization (International Energy Agency, 2006). The objective of this study was to evaluate the Extent and Causes of Fuelwood Collection in the seven communities in and around the Kasewe Reserved Forest, Sierra Leone.

\section{MATERIALS AND METHODS}

Area of Study: The research was conducted in Kasewe Reserved Forest; the forest cover is a region of slopes on the outskirt between Moyamba and Tonkolili Districts of Sierra Leone. It is assigned as a forest reserve and contains dampish semi-deciduous and evergreen woods that covers a zone of $1.224 \mathrm{~km}^{2}$. It comprised of volcanic stone, and the slopes stand about $500 \mathrm{~m}$ over the interior plains of the nation. The forest is situated along the Bo-Freetown Highway around Moyamba Junction, explicitly in the Kori and Yoni Chiefdom of Moyamba and Tonkolili district, respectively. Like any other part of the country, the study area is dominated by two seasons (rainy and dry).

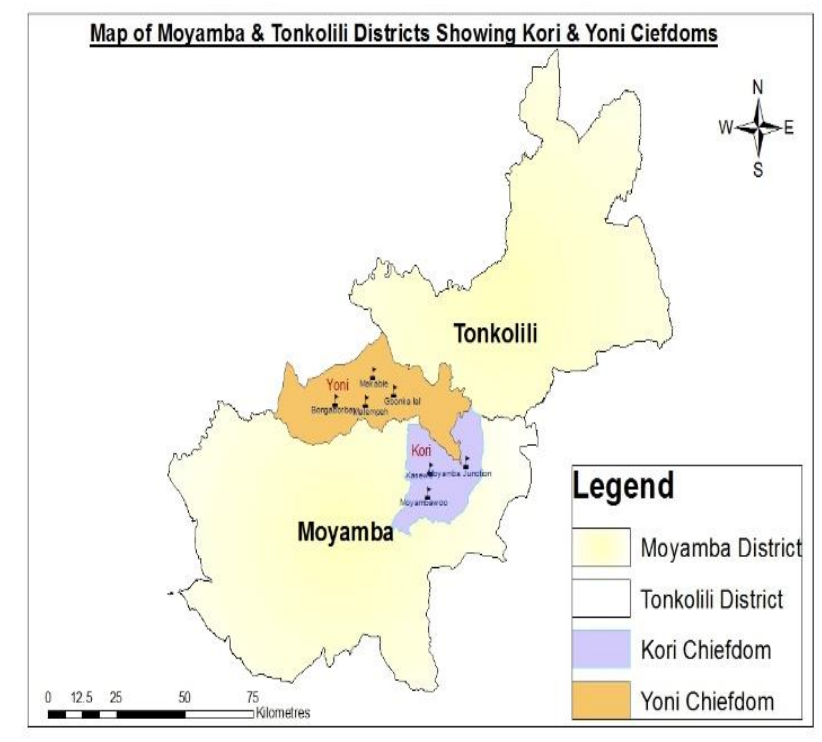

Fig 1. Map of the study area. 
Data Collection: Primary data used for the study was obtained through the use of structured questionnaires and interviews of the resident communities within and around Kasewe forest households. The secondary sources of data used came from published texts, journals, and online and offline computer resources. Seven (7) villages within and around the forest reserved were selected for the study. These are; Moyamba woo, Kasawe, Bongababay, Gbonka Lal, Malelmpeh, Makabie, and Moyamba junction

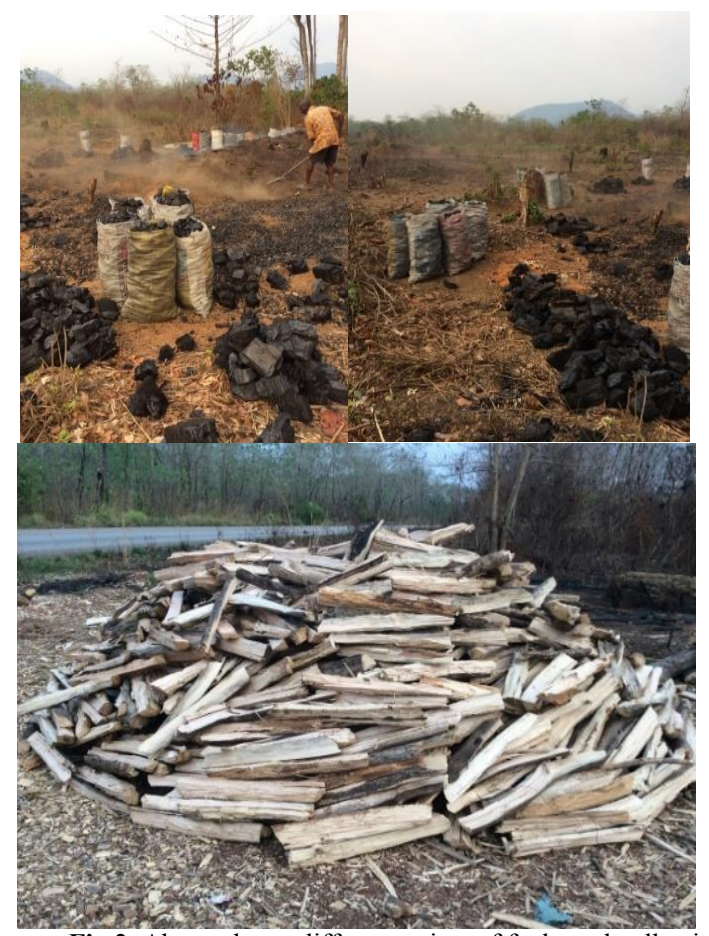

Fig 2. Above shows different points of fuelwood collection

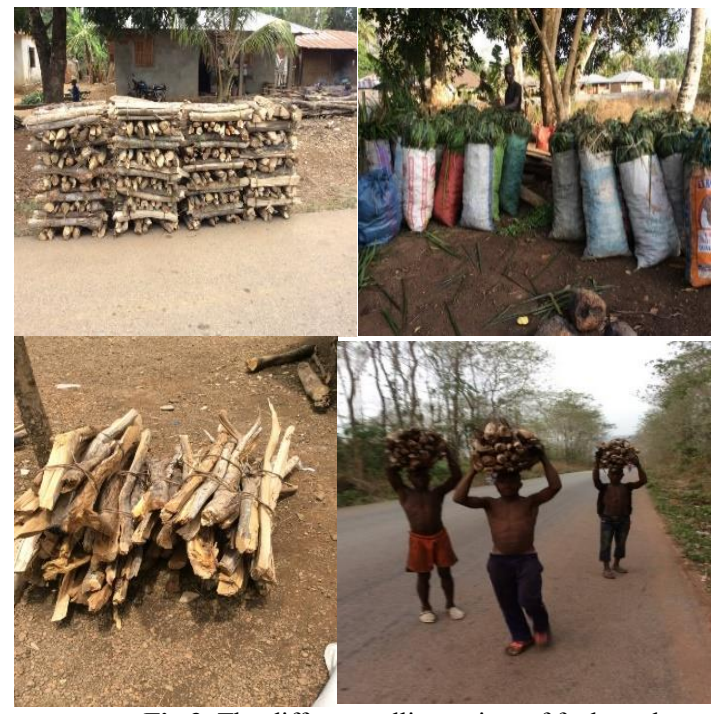

Fig 3. The different selling points of fuelwood.

Population and Sampling: The population of this study involved all categories of people that utilize fuelwood. The sampling procedure employed was the stratified random technique. Respondents of these communities were randomly selected to get a sample frame of 50 . The size of the village determined the number of questionnaires administered per village.

Questionnaire Survey: Semi-structured interviews were considered to be the most appropriate method of sourcing primary data from collectors (harvesters), traders, and users. The interview schedules were comprised of closed-ended and open-ended questions directed to both fuelwood sellers and users. Critical data sought from fuelwood sellers were about plant species, prices, and volumes. The questionnaire for the fuelwood users sought data on the socio-economic profile of people using fuelwood, woodland, and conservation practices and who make decisions in the harvesting and management of fuelwood. As aforementioned, the researcher preferred semistructured interviews as it would allow for sourcing data from people who could not read or write and seek clarifications on issues not fully understood. However, the questionnaire contains information for both sellers and users needed for a conclusion to be drawn.

Data Analysis: The data of this study were analyzed using Microsoft Excel in order to derive simple percentages and presented in tables for easy understanding and interpretation of results.

Permission to Conduct the Study: Permission to conduct the study was sought from the relevant authorities in the study area. The process of getting authorization involved an explanation of what type of data was required for the research and how the data was to be acquired. Special permission was also sought from the critical respondents involved in the study.

\section{RESULTS AND DISCUSSION}

Table 1 shows the species preference for fuelwood among the two major tribes in the study area (Themne and Mende). Almost all of the fuelwood users and collectors in the study area, 92\% indicated that they prefer Phyllanthus discoideus for fuelwood. Harungana madagascariensis and Hymenocrdai lyrata $38(76 \%)$ and 23 (46\%) respectively were also highly desired. The last preferred species that was available was Anisophyllea laurina 21(42\%). The table 3 shows the peaking activities of the fuelwood collector in the study area. The result in the table indicate that fuelwood activities were intense throughout the year but peaks late dry season (April May). The result presented in table 4 shows the factors that were responsible for the choice of firewood as the primary source of energy for cooking and other domestic activities. The availability and accessibility ensure fast cooking process and relatively cheap were by far the most common answers, among many other factors were recorded respectively for the choice of preference. 
Table 1. Shows the species use for fuelwood as reported by the 50 respondents with multiple choices.

\begin{tabular}{|c|c|c|c|c|}
\hline Local name & Scientific name & $\begin{array}{l}\text { No. of } \\
\text { Mende } \\
\text { users }\end{array}$ & $\begin{array}{l}\text { No. of } \\
\text { Themne } \\
\text { users }\end{array}$ & Note \\
\hline Gbavagie & Hymenocrdai lyrata & 23 & 0 & $*$ \\
\hline Tujuie/kasaika & Phyllanthus discoideus & 22 & 24 & $*$ \\
\hline Dowie/kabise & Parinari excelsa & 17 & 5 & $* * *$ \\
\hline Balie/kapale & Harungana madagascariensis & 14 & 24 & $*$ \\
\hline Kubuie/iron stick & Phyllocosmus sacoglottis & 13 & 3 & ** \\
\hline Kabempe/Black tombla & Dialium guinaeense & 10 & 12 & $* * *$ \\
\hline Kagboth/dorque & Diospyros heudelotii & 7 & 10 & $*$ \\
\hline
\end{tabular}

Table 2. Shows Species of plants used for charcoal production and firewood.

\begin{tabular}{|c|c|c|c|c|}
\hline Local name & Scientific name & $\begin{array}{l}\text { No. of respondents } \\
\text { with knowledge of } \\
\text { the use of the species }\end{array}$ & $\begin{array}{l}\text { No. of respondents with } \\
\text { less or no knowledge of } \\
\text { the use of the species }\end{array}$ & Notes \\
\hline Tujuie/kasaika & Phyllanthus discoideus & $46(92 \%)$ & 4 & $*$ \\
\hline Balie/kapale & $\begin{array}{l}\text { Harungana } \\
\text { madagascariensis }\end{array}$ & $38(76 \%)$ & 12 & * \\
\hline Gbavagie & Hymenocrdai lyrata & $23(46 \%)$ & 27 & * \\
\hline Kabempe/Black tombla & Dialium guinaeense & $22(44 \%)$ & 28 & $* * *$ \\
\hline Kagboth/dorque & Diospyros heudelotii & $17(34 \%)$ & 33 & * \\
\hline Kubuie/iron stick & Phyllocosmus sacoglottis & $16(32 \%)$ & 34 & $* *$ \\
\hline Matches stick & Accacia mangium & $1(2 \%)$ & 49 & * \\
\hline Kakenth & Anisophyllea laurina & $0(0 \%)$ & 50 & * \\
\hline Yemeni & Gmelina arborea & $0(0 \%)$ & 50 & $* * *$ \\
\hline Ink Stick & Tectonia spp & $0(0 \%)$ & 50 & $* *$ \\
\hline Dowie/kabise & parinari excelsa & $0(0 \% 0$ & 50 & * \\
\hline
\end{tabular}

Table 3. The Peak activities of fuelwood collectors at a different time of the year.

\begin{tabular}{ll}
\hline Time of the year & No. of respondents \\
\hline Middle dry & $2(4 \%)$ \\
Late dry & $18(36 \%$ \\
Early rains & $8(16 \%)$ \\
All year & $18(36 \%)$ \\
Missing & $4(8 \%)$ \\
\hline
\end{tabular}

Table 4. The factors that are responsible for the preference of firewood as the primary source of energy for domestic use.

\begin{tabular}{lll}
\hline Factor & $\begin{array}{l}\text { No of } \\
\text { Respondents }\end{array}$ & $\begin{array}{l}\text { Missing/no } \\
\text { answer (n/a) }\end{array}$ \\
\hline $\begin{array}{l}\text { Availability and } \\
\text { accessibility }\end{array}$ & $49(98 \%)$ & $1(2 \%)$ \\
Fast & $44(88 \%)$ & $6(12 \%)$ \\
Cheap & $38(76)$ & $12(24 \%)$ \\
Convenient & $22(44 \%)$ & $28((56 \%)$ \\
Accustom & $3(6 \%)$ & $47(94 \%)$ \\
\hline
\end{tabular}

The extent and causes of fuelwood collection in the study area were analyzed and presented in table 3 and table 4, respectively. Their varied characteristics determine the intensity of species exploitation. In the study area, $92 \%$ of the fuelwood users and collectors indicated that they prefer Phyllanthus discoideus for fuelwood. Various reasons like the intensity of the heat produced by the species, straightforward to split, long burning hours, and its abundance were outlined for the choice of the species. Harungana madagascariensis and Hymenocrdai lyrata 38 (76\%) and 23 (46\%) respectively were also highly preferred for their high heat intensity, long burning hours, and availability were also the reasons stated. The last selected species that was available was Anisophyllea laurina 21(42\%), of which all respondents $21(42 \%)$ that mentioned it expressed desertification over its insufficient heat intensity, short time duration with fire. However, it is interesting to know that these preferred species of plants in the study area were not replanted or encouraged in any way. The reasons stated were, they have no other economic value rather than fuelwood and that, it germinates abundantly during rains without any effort made. However, the result also indicates that all the exotic species Accacia mangium, Gmelina arborea, and Tectonia spp were less preferred for fuelwood, and these were the species that were planted to reinstate the forest. The reason for the less preference of these species was due to the forest laws and policies and availability in only restricted parts of the forest. According to forest workers, the reason why these species of plants were planted is for their rapid growth rate and has also proven to withstand a variety of environmental stress. Therefore, this has ascertained the fact that the preferred species for fuelwood were not replanted or encourage in any way, but rather the less select species were the ones being replanted or encouraged through the support of the forestry department. Fuelwood activities were intensive throughout the year, but peaks late dry season $18(36 \%)$ of the respondents indicate that fuelwood activities peak in late dry (April - May). This is because most of 
the farm produce is finished, and there is no other source of livelihood, and as a result, they mostly engage in the sale of fuelwood. From the survey, it is observed that the forest is managed and control by the Mendes (Moyamba district) as the forest is more on the Mendes side than the Themnes (Tonkolili district). About $90 \%$ of the forest cover is on the Mende side. As a result, most of the harvest of fuelwood in the forest is done by the Mendes. A further threat to the existing forest is the high collection frequency (On average, the result of the survey indicates that fuelwood collectors collect fuelwood three days per week). In some instances, high volumes (using accessible vans for charcoal) are likely to increase further pressure on forest reserved. Hence one of the significant threats posed by fuelwood collectors is forest degradation $48(96 \%)$ of the respondents stated it as the most significant concern with the forest. Kasewe forest does not only supply fuelwood to the immediate villages in the study area, as stated in the literature, but it also supplies big towns and the city, especially charcoal. Therefore, with thousands of people depending on this forest for fuelwood supply and the current harvest frequency, this study anticipated an unsustainable harvest of fuelwood in the next 15 years if this trend of the current management continues. According to the Human Development Report (1997), such pressure is likely to worsen existing environmental degradation problems like soil and species loss, among others. A study by Tee et al., (2009) in Nigeria for instance, showed that excessive fuelwood harvesting led to massive soil erosion, decreased water quality, and dam siltation. Decreased woodlots and forest stands further increased pressure on remnant lots and reduced forest cover. Basic resource sustainability principles require that resource exploitation does not compromise its regenerative ability Mwendwa (2008). Often, local people have their traditional natural resource management system that reflects the management potential of their resources. The implication of these management strategies depends on the local people, their culture, and their socio-economic status Mwendwa (2008). By these knowledge systems, local people demonstrate their creative ability and knowledge to maintain their environment. This, however, becomes a site-specific or a localized understanding arising from the local people's interaction with the environment Erakhrumen, et al., (2010). Hence in the study area, a larger percentage of respondents, 38(76\%), indicate that some traditional customs and practices regulate fuelwood use in the forest. The majority 33(66\%) of the respondents indicated that the recognizable institution in charge of managing and controlling fuelwood harvesting was the central government and local government. The majority of the respondents, $38(76 \%)$, indicated that local government leadership issue permit for fuelwood harvest. $39(78 \%)$ of the respondents indicate that resident communities engage in conservation practices. These clearly show that there are no conflicting perceptions about the unsustainable fuelwood harvest in the study communities and hence $49(98 \%)$ of the respondents stated forest degradation as the significant threat faced by the forest as a result of the wild harvest of fuelwood, which will eventually lead to water shortage according to the findings of this survey. This is not because there are no regulations, but it is as a result of the weak laws and preferential treatment given by some collectors and lack of complete involvement of all the communities around the forest in its management. According to this survey, the people engaged in fuelwood collection are the less privileged in the community who are not gainfully employed (the poor) who still live on less than one dollar per day; the study indicates that $100 \%$ of the collector are unemployed. This is a result of a lack of job opportunities and other alternative sources of livelihood in the study area. With this, $100 \%$ of the respondents still rely on firewood for cooking since they present the cheapest means of energy for domestic use, especially firewood. At the same time, almost all of the charcoal produced was for sale because of the enormous economic returns of charcoal. Several studies have shown that such high unemployment is positively correlated to high fuelwood exploitation. In Nigeria, for instance Ikurekong et al., (2009) found that local fuel exploitation was most prevalent in communities with low income while Obua et al., (2010) found that overexploitation and unsustainable woodland exploitation is mainly prevalent in poorer communities. According to Clarke and Grundy (2004), poor people who are often desperate for survival, use the most readily available resource for survival and are more likely to engage in unsustainable fuelwood exploitation practices. To further justify that most of the people involved in fuelwood collection are poor, the study reveals that there are almost one means of transportation, which was head loads. This is because of a lack of financial strength to pay or cater to other means of transportation. The results also indicated that firewood is the primary source of energy in the study communities, the availability and accessibility, ensures fast cooking process, and relatively cheap was by far the most common answers, among many other factors which were recorded for the choice of preference. Like in other studies (Clarke and Grundy, 2004; Shackleton and Shackleton ,2004; Population Reference Bureau, 2001) this study found an apparent division of labor between genders, which indicates that more females $27(54 \%)$ were engaged in fuelwood collection than males 23(46\%). According to the Population Reference Bureau (2001), women in most developing countries are the ones in charge of domestic chores, including fuelwood collection. Another reason, according to this survey, was that males usually go to the farm very early, leaving the females behind to follow later. As a result, more females were found in the villages and were selected for an interview; another reason is that females are the direct users of fuelwood 
for domestic use and hence are more knowledgeable on issues surrounding fuelwood.

Conclusion: Fuelwood is one of the significant products of the forest of which the resident communities rely on for their livelihood and energy for domestic use. Fuelwood is the primary source of energy in the study communities, and Phyllanthus discoideus was the most preferred choice of species. Thus, this study concluded that fuel wool collectors are selective over what species they harvest and somewhat seasonal. The study also concluded that there is a high frequency of fuelwood harvest and the high collection frequency is a further threat to the existing forest.

Acknowledgments: The authors thank God for protecting and giving them insight at all times. He provides guidance through his undying love. They always have a pillar of strength in Him. They wish to express their indebtedness to everyone who contributed to the success of this work. Their gratitude goes to the District Forest Offer (DFO) Moyamba, for his support and guidance throughout this work. Thanks to the respondents who sacrificed their time by participating in the interviews. They appreciate the help of the Staff of kasewe Reserved Forest.

\section{REFERENCES}

Agarwala, SP (2006). Environmental Studies. Alpha Science International Ltd, London.

Bell, RHV (1978). Lake Malawi National Park, A Summary of the Issues in Lake Malawi National Park Master Plan (1981), National Parks and Wildlife, Lilongwe, Unpublished

Cecelski, E; Dunkerley, J; Ramsay, W (1979). Household Energy and the Poor in the Third World." in Resources for the Future. Washington, D.C.

Clarke, J; Grundy, IM (2004). The socio-economics of forest and woodland resource use: A hidden economy. Indigenous Forests and Woodlands in South Africa: Policy, People, and Practice. 2004 PP 167-193.

Cole-cline, RA (1984a). Towards an understanding of man-fire wood relations in Freetown (Sierra Leone)" Geoforum, 15(4):583-94.

Davison, OR (1985). Energy use patterns, Sierra Leone" Ottowa IDRC Manuscript Report 103e. Department of Water Affairs and Forestry (DWAF).

Eckholm, E; Foley, G; Barnard, G; Timberlake, L (1984). Fuelwood: the energy crisis that will not go away. Earthscan Publications, BED, London.

Erakhrumen, AA; Ogunsanwo, OY; Ajewole, OI (2010). Assessment of some other traditional uses of accepted agro-forestry fuelwood species in Akinyele and Ido Local Government Areas, Oyo State, Nigeria. Int. J. Soc. Forestry. 3 (1): $49-65$.
Foster, JB (1999). Marx's Theory of Metabolic Rift: Classical Foundations for Environmental Sociology. Am. J. Sociol. 105(2):366-405.

Heltberg, R; Arndt, TC; Sekhar, NU (2000). Fuelwood Consumption and Forest Degradation: A Household Model for Domestic Energy Substitution in Rural India." Land Econ. 76(2):213-232.

Ikurekong, EE; Esin, JO; Mba, CC (2009) Rural Fuelwood Exploitation in Mbo Local Government Area, Nigeria: EJESM. Vol. 2 No. 3, 2009.

International Energy Agency (2006). World Energy Outlook 2006. Paris, France

Joanne, IOA (1996). Rural subsistence and Protected Areas: Community use of the miombo woodlands of Lake Malawi National Park. Thesis, University College London, Pp16.

Makhado, RA; von Maltitz, GP; Potgieter, MJ; Wessels, DCJ (2009). Contribution of Woodland Products to Rural Livelihoods in the Northeast of Limpopo Province, South Africa: S. Afr. Geogr. J. 91 (1) 46-53.

Mwendwa, R (2008). Role of Communities in Natural Resource Management: Proceedings of the 4th International Conference, Moi University July 29 August 1, 2008. Nairobi, Kenya.

Obua, J; Agea, J; Ogwal, JJ (2010). Status of Forest in Uganda. Afr. J. Ecol., 48, 853-859

Population Reference Bureau (2001). Women, Men, and Environmental Change: The Gender Dimensions of Environmental Policies and Programs. Washington DC, USA.

Shackleton, CM; Shackleton, SE (2004). Use of woodland resources for direct household provisioning. Indigenous Forests and Woodlands in South Africa: Policy, People, and Practice. 2004 pp 195-196.

Soussan, J (1998). Primary Resources and Energy in the Third World. Routledge, London.

Stern, PC; Dietz, T; Ruttan, VW; Socolow, RH; Sweeney, JL (1997). Environmentally Significant Consumption: Research Directions." Washington, D.C.: National Academy Press.

Tee, NT; Ancha, PU; Asue, J (2009). Evaluation of fuelwood consumption and Implications on the environment: a case study of Makurdi area in Benue State, Nigeria. J. Appl. Biosci. 19: 104- 1048. 